\title{
Öğretmenlerin Perspektifinden Sınıf Yönetimi
}

\author{
Doç. Dr. Necla Dönmez Usta ${ }^{1^{*}}$ \\ Doç. Dr. Neslihan Ültay ${ }^{2}$ \\ Doç. Dr. Eser Ültay ${ }^{3}$
}

Geliş tarihi: 14.03.2020

Kabul tarihi: 01.06.2020

\section{Atıf bilgisi: \\ IBAD Sosyal Bilimler Dergisi \\ Sayı: $8 \quad$ Sayfa: 209-225}

Yıl: 2020 Dönem: Güz

This article was checked by iThenticate. Similarity Index 17\%

Bu makalede araştırma ve yayın etiğine uyulmuştur.

${ }^{1}$ Giresun Üniversitesi, Türkiye, necladonmezusta@gmail.com,

ORCID ID 0000-0002-8075-7446

${ }^{2}$ Giresun Üniversitesi, Türkiye, neslihanultay@gmail.com ORCID ID 0000-0002-9783-0486

${ }^{3}$ Giresun Üniversitesi, Türkiye, eserultay@gmail.com

ORCID ID 0000-0001-6839-6361

\footnotetext{
* Sorumlu yazar
}

ÖZ

$\mathrm{Bu}$ çalışmanın amacı öğretmenlerin sınıf yönetimi hakkındaki görüşlerinin bazı değişkenler açısından incelenmesidir. Bu değişkenler, "motivasyon", "zaman", "iletişim" ve özel öğrencilerin davranışlarının yönetimi" olarak belirlenmiştir. Bu çalışma, nitel araştırma yaklaşıma uygun olarak yürütülmüş bir örnek olay çalıșmasıdır. Çalışma grubunu, Türkiye'nin farklı bölgelerinde görev yapan 50 öğretmen oluşturmaktadır. Veri toplama aracı olarak araştırmacılar tarafindan geliştirilen ve dokuz açık uçlu sorudan oluşan yarı yapılandırılmış görüşme formu kullanılmıştır. Veriler yüz yüze ve/veya internet üzerinden online görüşmeler yapılarak toplanmıştır. Bu görüşmeler 20-25 dakika sürmüştür. Veriler içerik analizi tekniği ile analiz edilmiștir. Analiz sonuçlarına göre öğretmenlerin öğrenme ortamlarında motivasyonu bozan davranışları bildikleri, zamanı etkili kullanmak için zaman tuzaklarına karșı önlem aldıkları, iletişime önem verdikleri ve sınıfta özel öğrencilerin davranışlarının nasıl yönetilmesi gerektiğinin farkında oldukları söylenebilir.

Anahtar Kelimeler: Sınıf Yönetimi, Motivasyon, Zaman Yönetimi, İletișim, Özel Öğrencilerin Davranışlarının Yönetimi 


\title{
Classroom Management Perspective of Teachers
}

\author{
Assoc. Prof. Dr. Necla Dönmez Usta ${ }^{1 *}$ \\ Assoc. Prof. Dr. Neslihan Ültay ${ }^{2}$ \\ Assoc. Prof. Dr. Eser Ültay ${ }^{3}$
}

First received: 14.03 .2020

Accepted: 01.06.2020

\section{Citation:}

IBAD Journal of Social Sciences

Issue: 8

Pages: 209-225

Year: 2020 Session: Fall

This article was checked by iThenticate. Similarity Index 17\%

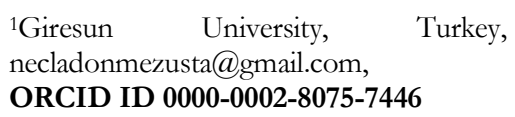

* Corresponding Author

\begin{abstract}
The aim of this study is to evaluate the views of teachers about classroom management in terms of some variables. These variables are defined as "motivation", "time", "communication" and "management of special students' behaviours ". This study is a case study conducted in accordance with the qualitative approach. The study group was 50 teachers from different regions of Turkey. Data collection tool was a semi-structured interview form consisted of nine open-ended questions developed by the researchers. The data were collected by the interviews through face to face and/or the internet. These interviews lasted about 20-25 minutes. Data were analyzed by using content analysis technique. According to the results of the analysis, it can be said that the teachers know the motivational behaviors in learning environments, take precautions against time traps to use time effectively, care about communication and are aware of how the behavior of special students should be managed in the classroom.
\end{abstract}

Keywords: Classroom Management, Motivation, Time Management, Communication, Management of Special Students' Behaviours 


\section{INTRODUCTION}

Classroom management; it is the continuation of the opportunities and processes, learning order, environment, and rules necessary for creating an environment in which learning takes place (Brophy, 1983; Brophy, 1988). Teachers are responsible for classroom management in learning environment (Wragg, 1993; Aydın, 1998). In this sense, teachers who do not have effective classroom management skills may be ineffective during the learning and teaching process. However, teachers who have effective classroom management skills can overcome difficulties in the learning environment more easily (Aydın, 1998; Başar, 2004; Burden, 1995; Edwards, 1993; Erden, 1998).). Teachers can make positive or negative effects on the students' behaviors through classroom management attitudes. Teacher's positive effect on student can be provided by positive communication process established between teacher and student (Şişman \& Turan, 2004). Glasser (1990) notes that the vast majority of disciplinary problems encountered in learning environments are caused by the strain of finding out that the students will listen and communicate. According to Jones and Jones (1998), teachers who are the designers of the learning environments should pay attention to the current situation, to take responsibility for expressions using personal pronouns, direct conversation with the student, gentle conversation, eye communication and awareness of nonverbal communication in developing the relationship with the students. The more the teacher constitutes this communication, the more the students gains his/her educational goals (Aydin, 2000; Celep, 2008). Thus, the construction of effective communications, which is the responsibility of the teacher, is one of the most important components of the success of students (Şimşek \& Altınkurt, 2010; Ültay, Ültay \& Dönmez Usta, 2018). Students can not establish any communications in a learning environment if they have non-motivated. Also, students probably can not perform the behavior they want to learn unless they are motivated. For this reason, a non-motivated student can not be expected to fulfill his/her requirements (Boiche \& Sarrazin, 2007). On the other hand, a student with high academic motivation will actively participate in the course, make effort, focus on the goal, and perform important learning tasks (Dönmez Usta \& Turan Güntepe, 2017; Hidi \& Harackiewicz, 2000; Linnenbrink \& Pintrich, 2002). Besides, studies in the field of education show that academic motivation is the main determinant of academic performance and achievement (Green, Nelson, Martin \& Marsh, 2006; Linnenbrink \& Pintrich, 2002).

In some studies, it was found that the majority of the teachers have low motivation and performances, with high stress and burnout. This may be due to the personal circumstances and the working conditions of the teachers. A good teaching-learning process that teachers apply in their classroom may be also directly related to their living and working conditions. (Brissie, Hoover- Dempsey \& Bassler, 1988; Schwab, Jackson \& Schuler, 1986). Teachers' classroom management skills are applied in their learning environment of primary importance in obtaining desired educational outcomes (Ağaoğlu, 2008), but these skills require guidance to the student in the context of correcting and evaluating (reviewing) undesired behaviors (Jones \& Jones, 1998). According to the results of the study conducted by Türnüklü and Yildiz (2002), in which they investigated the strategies of coping with the unwanted behaviors of the students, the teachers try to establish the eye contact the most frequently against the unwanted student behaviors, they also use conversation about the behavior, remind the classroom rules, call the student's name, as well as apply to the strategies such as motivating students to the lessons. It was determined that the teachers use different methods when they encounter a problem in the classroom including ignoring, allocating a large part of the course to advise students, trying to solve the problem by talking with the student and warning students through body language, relocating the students. They also report students to the school management in serious disciplinary problems (Kazu, 2007).

Unwanted behavior of the students may also be related to the management of special students. According to the results of the study conducted by Sadioğlu, Batu and Bilgin (2012), teachers were determined to experience problems related to the management of special students' behaviors. Unlike Sadioğlu et al., (2012) the study conducted by Güleryüz (2009), it was also determined that special students who have some problems with their classmates. At this point, the management of special students' behaviors becomes important.

Considering all these, it can be said how effective teachers are in classroom management. Also, teacher has features that are effective significantly the quality of classroom management (Dönmez Usta \& Turan 
Güntepe, 2017; 2019; Ültay \& Ültay, 2015). From this point of view, the fact that the teacher, as the most effective element of classroom management, can provide classroom management that facilitates learning requires students to know their needs individually and as a group (Başar, 2004). The teacher, who does not know the student's needs, may encounter undesirable behaviors in the learning environment. The disruptive behaviours experienced in classroom environment are at the top of the list of problems that teachers perceive in their profession (Nelson, 2002). Teachers may keep some variables under control in the learning environment to avoid unwanted behavior. In this content; the variables of this study are "motivation", "time", "communication" and "management of special students' behaviors.

There are many studies on classroom management in the literature. These studies investigation different extent of classroom management. For example, these studies are teachers' opinions about classroom management (Güven \& Cevher, 2005; Erol, 2006), students' opinions, attitude or perception about class management competencies of their teachers (Güven \& Akdağ, 2002; Ekici, 2002; Demirtaş \& Kahveci, 2010; Gündüz, 2014), an examination of the relationship between class management and different variables (Nakamura, 2000; Lewis, 2001; Atıc1, 2002; Akın \& Koçak, 2007; Şentürk, 2007; Arsal, 2014; Demirtaş, 2006; Öksüz, Çevik, Baba \& Güven, 2011; Ekici, Aluçdibi \& Öztürk, 2012) and special students' behaviors (Çelik, 2006; Çitil \& Ataman, 2008; Sezer, 2015). In these studies becomes apparent the importance of classroom management in the learning environment. For this reason, it is believed that the relation of classroom management with motivation, time, communication and special student's behaviors' management should be examined within the scope of the study. As a result of the study, it is thought that the opinions of a wide participant will contribute to the field are sought in the study:

- How do teachers relate motivation with classroom management?

- How do teachers relate time with classroom management?

- How do teachers relate communication with classroom management?

- How do teachers relate motivation with classroom management?

- How do teachers relate special student's behaviors' management with classroom management?

\section{METHODOLOGY}

This study is a case study conducted in accordance with the qualitative approach. Case studies are more of a research method with qualitative research approaches (Çepni, 2007; Yıldıı \& Şimşek, 2011 ). According to Yin (2003) case study is an ideal methodology when an in-depth investigation is needed situation. Also, one of the most important features of this method is that one aspect of the research problem can be studied in depth. The most important advantage of this method is that it gives the opportunity to concentrate on a particular situation of a problem (Wellington, 2000). Besides, this method focuses on the nature of a situation and allows different data collection techniques to be used together (Cohen \& Manion, 1994).

In this research, the case study was used because this research method gave the opportunity to investigate the properties of a sample group deeply (Creswell, Plano Clark, Gutmann \& Hanson, 2003).

\section{Study Group}

The study group was 50 teachers, who selected with an easy accessible sampling method, from various regions of Turkey. In the study, "motivation", "time management", "communication" and "management of students' behaviour with special education need in the classroom" were investigated, and the questions about the "motivation" were asked to 18 teachers, questions related to "time management" were asked to 12 teachers, the questions related to "communication" were asked to 10 teachers, "management of students' behaviour with special education need in the classroom" were asked to 10 teachers. The demographic qualifications of the participants are shown in Table 1. 
Table 1. Demographic information about the participants $(N=50)$

\begin{tabular}{|c|c|c|c|c|}
\hline \multicolumn{5}{|c|}{ Motivation } \\
\hline Teachers & Gender & Branch & $\begin{array}{c}\text { Professional Experience } \\
\text { (month/year) }\end{array}$ & Graduated University \\
\hline $\mathrm{T} 1$ & Male & English & 2 months & Yıldız Technical \\
\hline $\mathrm{T} 2$ & Female & ElementaryElementary & 2.5 years & Atatürk \\
\hline $\mathrm{T} 3$ & Female & German & 2.5 years & Gazi \\
\hline $\mathrm{T} 4$ & Female & Preschool & 17 years & $\begin{array}{l}\text { Belgium Kindergarten } \\
\text { Education School }\end{array}$ \\
\hline T5 & Male & Literature & 19 years & Marmara \\
\hline T6 & Male & Mathematics & 14 years & Atatürk \\
\hline $\mathrm{T} 7$ & Female & Literature & 14 years & KTÜ \\
\hline $\mathrm{T} 8$ & Female & Elementary & 31 years & Atatürk \\
\hline T9 & Male & Elementary & 9 years & KTÜ \\
\hline $\mathrm{T} 10$ & Female & Elementary & 20 years & Ondokuz Mayıs \\
\hline $\mathrm{T} 11$ & Male & Elementary & 12 years & Afyon Kocatepe \\
\hline $\mathrm{T} 12$ & Male & Social studies & 25 years & Ondokuz Mayıs \\
\hline $\mathrm{T} 13$ & Female & Mathematics & 10 years & Marmara \\
\hline $\mathrm{T} 14$ & Female & English & 6 years & Near East University \\
\hline $\mathrm{T} 15$ & Female & Biology & 2 years & Atatürk \\
\hline $\mathrm{T} 16$ & Female & Literature & 3 years & Bozok \\
\hline $\mathrm{T} 17$ & Male & Elementary & 24 years & Trakya \\
\hline $\mathrm{T} 18$ & Male & Elementary & 1 year & Giresun \\
\hline \multicolumn{5}{|c|}{ Time } \\
\hline Teachers & Gender & Branch & $\begin{array}{c}\text { Professional Experience } \\
\text { (month/year) }\end{array}$ & Graduated University \\
\hline T19 & Male & Social studies & 2 years & Çukurova \\
\hline $\mathrm{T} 20$ & Female & Elementary & 11 years & Niğde \\
\hline $\mathrm{T} 21$ & Female & Turkish & 7 years & Amasya \\
\hline $\mathrm{T} 22$ & Female & Elementary & 19 years & Hacettepe \\
\hline $\mathrm{T} 23$ & Female & Literature & 8 months & Pamukkale \\
\hline $\mathrm{T} 24$ & Female & English & 10 years & Selçuk \\
\hline $\mathrm{T} 25$ & Female & Guidance & 7 years & Atatürk \\
\hline $\mathrm{T} 26$ & Male & Elementary & 8 years & Ağrı \\
\hline $\mathrm{T} 27$ & Male & Science & 12 years & Ondokuz Mayıs \\
\hline $\mathrm{T} 28$ & Male & Elementary & 36 years & Giresun \\
\hline $\mathrm{T} 29$ & Female & Elementary & 11 years & Giresun \\
\hline $\mathrm{T} 30$ & Male & Elementary & 25 years & Bolu \\
\hline \multicolumn{5}{|c|}{ Communication } \\
\hline Teachers & Gender & Branch & $\begin{array}{c}\text { Professional Experience } \\
\text { (month/year) }\end{array}$ & Graduated University \\
\hline T31 & Male & Turkish & 12 years & Kocatepe \\
\hline $\mathrm{T} 32$ & Male & Mathematics & 7 years & Ondokuz Mayıs \\
\hline T33 & Male & Anesthesia & 7 years & Atatürk \\
\hline T34 & Male & Guidance & 11 years & KTÜ \\
\hline T35 & Male & Elementary & 31 years & Giresun \\
\hline $\mathrm{T} 36$ & Male & Philosophy & 22 years & Cumhuriyet \\
\hline $\mathrm{T} 37$ & Female & Preschool & 9 years & Giresun \\
\hline $\mathrm{T} 38$ & Female & Biology & 22 years & Ondokuz Mayıs \\
\hline T39 & Female & Tourism & 30 years & Gazi \\
\hline $\mathrm{T} 40$ & Female & Special education & 8 years & KTÜ \\
\hline \multicolumn{5}{|c|}{ Management of special students in the class } \\
\hline Teachers & Gender & Branch & $\begin{array}{c}\text { Professional Experience } \\
\text { (month/year) }\end{array}$ & Graduated University \\
\hline T41 & Male & Elementary & 32 years & KTÜ \\
\hline $\mathrm{T} 42$ & Male & Geography & 25 years & Dicle \\
\hline $\mathrm{T} 43$ & Female & Elementary & 11 years & KTÜ \\
\hline T44 & Male & Elementary & 30 years & Gazi \\
\hline $\mathrm{T} 45$ & Female & Special education & 5 years & Selçuk \\
\hline $\mathrm{T} 46$ & Male & Elementary & 21 years & Atatürk \\
\hline $\mathrm{T} 47$ & Male & Art & 15 years & KTÜ \\
\hline $\mathrm{T} 48$ & Female & Turkish & 4 years & Gazi \\
\hline T49 & Female & Elementary & 19 years & Selçuk \\
\hline T50 & Male & Elementary & 10 years & KTÜ \\
\hline
\end{tabular}




\section{Data Collection Tool}

Semi-structured interview form developed by researchers was used as data collection tool in the research. Data were collected through face-to-face or internet interviews with the teachers and these interviews lasted approximately 20-25 minutes. The questions directed to the teachers are presented in Table 2 .

Table 2. Questions used in the interview

\begin{tabular}{|c|c|c|}
\hline Dimensions & & Questions \\
\hline \multirow[t]{3}{*}{ Motivation } & 1. & $\begin{array}{c}\text { What do you do to provide motivation in the learning } \\
\text { environment? }\end{array}$ \\
\hline & 2. & $\begin{array}{c}\text { How does high motivation influence learners' learning in } \\
\text { classroom learning? }\end{array}$ \\
\hline & 3. & $\begin{array}{l}\text { What are the disruptive behaviours affecting negatively the } \\
\text { motivation of students? }\end{array}$ \\
\hline \multirow[t]{3}{*}{ Time } & 4. & $\begin{array}{l}\text { What do you do when you encounter disturptive behaviours } \\
\text { that affect your time use during the lesson? }\end{array}$ \\
\hline & 5. & How do you manage time effectively? \\
\hline & 6. & $\begin{array}{l}\text { How do events such as excursions, ceremonies, conferences } \\
\text { on school influence your time management? }\end{array}$ \\
\hline Communication & 7. & $\begin{array}{l}\text { What are you doing to overcome the difficulties of } \\
\text { communication with the students in the class? }\end{array}$ \\
\hline \multirow{2}{*}{$\begin{array}{c}\text { Management of students' } \\
\text { behaviour with special } \\
\text { education need in the } \\
\text { class }\end{array}$} & 8. & $\begin{array}{l}\text { What kind of precautions do you take for a student is known } \\
\text { to be special in your class? }\end{array}$ \\
\hline & 9. & $\begin{array}{l}\text { What are the activities that you do for the students who are } \\
\text { gifted in the class? }\end{array}$ \\
\hline
\end{tabular}

Immediately after the questions were prepared, it was examined by two educational sciences experts and necessary revisions were made. In addition, according to this experts' opinion, necessary changes had been made in terms of language and clarity of questions.

\section{Data Analysis}

In the analysis of the data collected in the research, the content analysis technique was used in the qualitative data analysis. The basic process in content analysis is to gather similar data within the framework of certain concepts and themes and to organize and interpret them in a way that the reader can understand (Bauer Martin 2003; Yıldırım \& Şimşek, 2011). In this direction, after the collected data was arranged, data reduction was made. Codes from these reduced data and themes from codes were created. In order to determine the reliability in the study, the percentage of compliance was calculated by Miles and Huberman (1994) with the percentage of agreement formula $(\%$ of agreement $=$ [agreement $/$ disagreement + agreement] $* 100) .91$ found. If this value is higher than $70 \%$, it is an indication that the qualitative analysis of the data is reliable.

\section{Quality in Research}

Before the application, the semi-structured interview form developed by the researchers was checked by two educational sciences experts and their recommendations were taken into account In addition, prior to the application of the data collection tool, to ensure the appearance of the validity made some process. This process four educational sciences experts and one Turkish language expert had been checked in terms of intelligence and clarity of the data collection tool and necessary arrangements had been made. In addition, the interview page has been rearranged in terms of readability and legibility in the opinion of experts.

Validity and reliability are the necessary concepts that determine the qualitative nature of quantitative research, while qualitative researches use different terms. According to Lincoln and Guba (1985), a quality work must be credible, transferable, consistent and verifiable. Before the data collection process began, teachers were provided with information such as "applications and data used only for research purposes" and "no data other than some demographic information will be shared with readers of the study" by the researcher. The purpose of this information is to increase the credibility of working and to 
provide teachers with a comfortable and sincere response during the data collection process. In order to increase the credibility and consistency of the answers given by the teachers to the questions in the interview, necessary reductions were made three times at different times and places and critical answers were determined and code pools were created and these codes were tried to be separated into the themes. The validity and reliability of these steps are provided by expert opinions.

\section{Ethics in Research}

Permission was obtained for the data collected from the teachers who participated in the research. It has been reported that this collected data will be shared with the reader. It is also stated that some demographic information of teachers will be shared with the readers and their consents were taken in order not to be harmed in any way (Cohen \& Manion, 1994; Drew, Hardman and Hart, 1996). In the process of data collection, some specific dialogues between researchers and teachers were not reflected in the study on privacy and confidentiality principles. However, teachers who participated in the data collection process within the framework of research ethics were coded as T1, T2, T3, ..., T50 to provide name confidentiality.

\section{FINDINGS}

The findings on communication, time, motivation, and the management of special students in the class, are presented, respectively.

\section{The Findings of "Motivation" Dimension}

The results related to providing the motivation in the learning environment are presented in Table 3.

Table 3. The general codes related to motivation $(N=18)$

\begin{tabular}{|c|c|c|c|c|c|c|c|c|c|c|c|c|c|c|c|c|c|c|}
\hline \multirow{2}{*}{ Codes } & \multicolumn{18}{|c|}{ Teachers (T) } \\
\hline & 1 & 2 & 3 & 4 & 5 & 6 & 7 & 8 & 9 & 10 & 11 & 12 & 13 & 14 & 15 & 16 & & 18 \\
\hline Eye contact & $\sqrt{ }$ & $\sqrt{ }$ & $\sqrt{ }$ & $\sqrt{ }$ & $\sqrt{ }$ & $\sqrt{ }$ & $\sqrt{ }$ & $\sqrt{ }$ & $\sqrt{ }$ & $\sqrt{ }$ & $\sqrt{ }$ & & $\sqrt{ }$ & & $\sqrt{ }$ & & & $5 \sqrt{ }$ \\
\hline Providing physical equipment & & $\sqrt{ }$ & $\sqrt{ }$ & $\sqrt{ }$ & & & & & & $\sqrt{ }$ & $\sqrt{ }$ & & $\sqrt{ }$ & $\sqrt{ }$ & $\sqrt{ }$ & $\sqrt{ }$ & $\sqrt{ }$ & \\
\hline Controlling homeworks & $\sqrt{ }$ & $\sqrt{ }$ & $\sqrt{ }$ & & & $\sqrt{ }$ & & $\sqrt{ }$ & & $\sqrt{ }$ & $\sqrt{ }$ & & $\sqrt{ }$ & & $\sqrt{ }$ & & $\sqrt{ }$ & \\
\hline $\begin{array}{l}\text { Emphasizing the importance of the } \\
\text { subject }\end{array}$ & & & $\sqrt{ }$ & & $\sqrt{ }$ & & & $\sqrt{ }$ & & $\checkmark$ & & $\sqrt{ }$ & & $\sqrt{ }$ & $\sqrt{ }$ & $\sqrt{ }$ & & $\sqrt{ }$ \\
\hline Notify the target & & & & $\sqrt{ }$ & & $\sqrt{ }$ & & & & $\sqrt{ }$ & & $\sqrt{ }$ & & $\sqrt{ }$ & & $\sqrt{ }$ & & $\sqrt{ }$ \\
\hline Guidance & & & & & $\sqrt{ }$ & & $\sqrt{ }$ & & $\sqrt{ }$ & & & $\sqrt{ }$ & & $\sqrt{ }$ & & $\sqrt{ }$ & & \\
\hline Warning & & & & & & & $\sqrt{ }$ & & $\sqrt{ }$ & & & $\sqrt{ }$ & $\sqrt{ }$ & & & $\sqrt{ }$ & & \\
\hline Rewarding & & & & $\sqrt{ }$ & & & & $\sqrt{ }$ & & & $\sqrt{ }$ & & $\sqrt{ }$ & & & $\sqrt{ }$ & & \\
\hline Giving a word & & & $\sqrt{ }$ & & & & & & & & & & $\sqrt{ }$ & & & & $\sqrt{ }$ & \\
\hline Experimentation & & & & & & & & & & & & & & & $\sqrt{ }$ & & & \\
\hline
\end{tabular}

In Table 3, it is seen that 10 general -codes were determined related to motivation. The -code of eye contact $(\mathrm{f}=15)$ is the foreground of these -codes. The other -codes are providing physical equipment $(\mathrm{f}=11)$, controlling homeworks ( $\mathrm{f}=10)$, emphasizing on the importance of the subject $(\mathrm{f}=9)$, notifying the target ( $\mathrm{f}=9$ ), guidance ( $\mathrm{f}=6$ ), warning (5), rewarding (5), giving a word (3), experimentation (1).

The response of the second question expressed as "How does high motivation influence learners' learning in classroom learning?" are given in Table 4.

Table 4. The codes related to high motivation

\begin{tabular}{|c|c|c|c|c|c|c|c|c|c|c|c|c|c|c|c|c|c|c|}
\hline \multirow[b]{2}{*}{ Codes } & \multicolumn{18}{|c|}{ Teachers (T) } \\
\hline & 1 & 2 & 3 & 4 & 5 & 6 & 7 & 8 & 9 & 10 & 11 & 12 & 13 & 14 & 15 & 16 & 17 & 18 \\
\hline Increasing self-confidence & $\sqrt{ }$ & $\sqrt{ }$ & $\sqrt{ }$ & $\sqrt{ }$ & $\sqrt{ }$ & $\sqrt{ }$ & & $\sqrt{ }$ & & $\sqrt{ }$ & & $\sqrt{ }$ & $\sqrt{ }$ & & $\sqrt{ }$ & & $\sqrt{ }$ & $\sqrt{ }$ \\
\hline $\begin{array}{l}\text { Contributing to the permanence of } \\
\text { the learning }\end{array}$ & & $\sqrt{ }$ & & $\sqrt{ }$ & & $\sqrt{ }$ & $\sqrt{ }$ & & $\sqrt{ }$ & & $\sqrt{ }$ & & $\sqrt{ }$ & $\sqrt{ }$ & & $\sqrt{ }$ & & \\
\hline $\begin{array}{c}\text { Increasing the attendance to the } \\
\text { courses }\end{array}$ & $\sqrt{ }$ & & & & $\sqrt{ }$ & $\sqrt{ }$ & & $\sqrt{ }$ & & $\sqrt{ }$ & & $\sqrt{ }$ & & & & & & $\sqrt{ }$ \\
\hline Facilitating to focus on the target & & $\sqrt{ }$ & & $\sqrt{ }$ & & & $\sqrt{ }$ & & & & & & $\sqrt{ }$ & $\sqrt{ }$ & $\sqrt{ }$ & & & \\
\hline
\end{tabular}


As can be seen from Table 4, 4 codes emerged from the answers given by the teachers to the second question of the interview. The code of "increasing self-confidence" (13) is the foreground of these themes. This code was followed by "contributing to the permanence of the learning" (9), "increasing the attendance to the courses" (7), "facilitating to focus on the target" (6).

"What are the behaviors that disrupt the motivation of students based on your experiences?" was answered by 18 teachers and the responses are shown in Table 5 .

Table 5. The codes related to behaviors that disrupt the motivation

\begin{tabular}{|c|c|c|c|c|c|c|c|c|c|c|c|c|c|c|c|c|c|c|}
\hline \multirow{2}{*}{ Codes } & \multicolumn{18}{|c|}{ Teachers (T) } \\
\hline & 1 & 2 & 3 & 4 & 5 & 6 & 7 & 8 & 9 & 10 & 11 & 12 & 13 & 14 & 15 & 16 & 17 & 18 \\
\hline $\begin{array}{l}\text { Lack of relating the information to } \\
\text { the everyday life }\end{array}$ & $\sqrt{ }$ & & $\sqrt{ }$ & $\sqrt{ }$ & & $\sqrt{ }$ & & $\sqrt{ }$ & & & $\sqrt{ }$ & $\sqrt{ }$ & & $\sqrt{ }$ & & $\sqrt{ }$ & $\sqrt{ }$ & $\sqrt{ }$ \\
\hline Reluctant teacher & $\sqrt{ }$ & & $\sqrt{ }$ & & & $\sqrt{ }$ & $\sqrt{ }$ & & $\sqrt{ }$ & & $\sqrt{ }$ & & $\sqrt{ }$ & & $\sqrt{ }$ & $\sqrt{ }$ & & \\
\hline $\begin{array}{l}\text { Having technological devices such as } \\
\text { tablet, smart, phone, laptop }\end{array}$ & & & $\sqrt{ }$ & & $\sqrt{ }$ & & & $\sqrt{ }$ & & $\sqrt{ }$ & & $\sqrt{ }$ & & & & & $\sqrt{ }$ & $\sqrt{ }$ \\
\hline Negative expressions of the teacher & $\sqrt{ }$ & $\sqrt{ }$ & & $\sqrt{ }$ & & & $\sqrt{ }$ & $\sqrt{ }$ & & & & $\sqrt{ }$ & & & & & $\sqrt{ }$ & \\
\hline $\begin{array}{l}\text { Using always the same tone of the } \\
\text { teacher }\end{array}$ & & $\sqrt{ }$ & & $\sqrt{ }$ & & & $\sqrt{ }$ & $\sqrt{ }$ & & & & & & & $\sqrt{ }$ & $\sqrt{ }$ & & $\sqrt{ }$ \\
\hline $\begin{array}{c}\text { Giving uncorrect answers to the } \\
\text { questions }\end{array}$ & & $\sqrt{ }$ & & & & $\sqrt{ }$ & & $\sqrt{ }$ & & & $\sqrt{ }$ & & $\sqrt{ }$ & & & $\sqrt{ }$ & $\sqrt{ }$ & \\
\hline Teasing of the friends & & $\sqrt{ }$ & & & & & & & & $\sqrt{ }$ & & & & $\sqrt{ }$ & & & & $\sqrt{ }$ \\
\hline Not interesting subjects & & & & & & & & $\sqrt{ }$ & & & & $\sqrt{ }$ & & & $\sqrt{ }$ & & $\sqrt{ }$ & \\
\hline
\end{tabular}

As can be seen from Table 5, 9 codes emerged from the answers teachers gave to the third question of the interview. The code of "lack of relating the information to the everyday life" (11) is the foreground of these codes. This code was followed by "reluctant teacher" (9), "having technological devices such as tablet, smart phone, laptop" (7), "negative expressions of the teacher" (7), "using always the same tone of the teacher" (7), "students' unwanted behaviours in class" (6), "giving uncorrect answers to the questions" (6), "teasing of the friends" (4), "not interesting subjects" (4).

The Findings of "Time" Dimension

For the fourth question of the interview which was "What do you do when you meet disturbances occurred in or out of the classroom that affect your me use during the lesson?" was answered by 12 teachers and the responses are given in Table 6.

Table 6. The codes related to disturbances occurred in or out of the classroom that affect time

\begin{tabular}{|c|c|c|c|c|c|c|c|c|c|c|c|c|}
\hline \multirow{2}{*}{ Codes } & \multicolumn{12}{|c|}{ Teachers (T) } \\
\hline & 19 & 20 & 21 & 22 & 23 & 24 & 25 & 26 & 27 & 28 & 29 & 30 \\
\hline Taking a break & $\sqrt{ }$ & $\sqrt{ }$ & $\sqrt{ }$ & $\sqrt{ }$ & $\sqrt{ }$ & & & $\sqrt{ }$ & $\sqrt{ }$ & $\sqrt{ }$ & $\sqrt{ }$ & $\sqrt{ }$ \\
\hline Warning & & $\sqrt{ }$ & $\sqrt{ }$ & & $\sqrt{ }$ & $\sqrt{ }$ & $\sqrt{ }$ & & $\sqrt{ }$ & $\sqrt{ }$ & $\sqrt{ }$ & $\sqrt{ }$ \\
\hline Joking & & $\sqrt{ }$ & & $\sqrt{ }$ & $\sqrt{ }$ & & & $\sqrt{ }$ & & $\sqrt{ }$ & $\sqrt{ }$ & $\sqrt{ }$ \\
\hline $\begin{array}{l}\text { Providing the } \\
\text { class lavout }\end{array}$ & & $\sqrt{ }$ & & $\sqrt{ }$ & & & $\sqrt{ }$ & & & $\sqrt{ }$ & $\sqrt{ }$ & $\sqrt{ }$ \\
\hline Making a deal & $\sqrt{ }$ & & $\sqrt{ }$ & & $\sqrt{ }$ & & & $\sqrt{ }$ & & & $\sqrt{ }$ & \\
\hline $\begin{array}{l}\text { Informing the } \\
\text { guidance } \\
\text { service }\end{array}$ & $\sqrt{ }$ & & & $\sqrt{ }$ & & & $\sqrt{ }$ & & & $\sqrt{ }$ & & $\sqrt{ }$ \\
\hline $\begin{array}{l}\text { Going into a } \\
\text { different place } \\
\text { less noisy }\end{array}$ & & $\sqrt{ }$ & & & & & $\sqrt{ }$ & $\sqrt{ }$ & & $\sqrt{ }$ & & $\sqrt{ }$ \\
\hline $\begin{array}{l}\text { Changing the } \\
\text { subject }\end{array}$ & $\sqrt{ }$ & & $\sqrt{ }$ & & $\sqrt{ }$ & & & & $\sqrt{ }$ & & & $\sqrt{ }$ \\
\hline $\begin{array}{l}\text { Attracting their } \\
\text { interests for the } \\
\text { first ten } \\
\text { minutes }\end{array}$ & & & $\sqrt{ }$ & & & $\sqrt{ }$ & & & & $\sqrt{ }$ & & $\sqrt{ }$ \\
\hline $\begin{array}{l}\text { Informing the } \\
\text { parents }\end{array}$ & $\sqrt{ }$ & & & & $\sqrt{ }$ & & & & $\sqrt{ }$ & & $\sqrt{ }$ & \\
\hline
\end{tabular}


As can be seen from Table 6,11 codes emerged from the answers teachers gave to the fourth question of the interview. The code of "taking a break" (10) is the foreground of these codes. This code was followed by "warning" (9), joking (7), "providing the class layout" (6), "making a deal" (5), "informing the guidance service" (5), "going into a different place less noisy" (5), "changing the subject" (5), "atrracting their interests for the first ten minutes" (4) and "informing the parents" (4).

For the fifth question of the interview which was "How do you manage time effectively?" was answered by 12 teachers and the responses are given in Table 7 .

Table 7. The codes related to manage time effectively

\begin{tabular}{|c|c|c|c|c|c|c|c|c|c|c|c|c|}
\hline \multirow{2}{*}{ Codes } & \multicolumn{12}{|c|}{ Teachers (T) } \\
\hline & 19 & 20 & 21 & 22 & 23 & 24 & 25 & 26 & 27 & 28 & 29 & 30 \\
\hline $\begin{array}{l}\text { Coming to the } \\
\text { class with } \\
\text { preparation }\end{array}$ & $\sqrt{ }$ & $\sqrt{ }$ & $\sqrt{ }$ & $\sqrt{ }$ & $\sqrt{ }$ & $\sqrt{ }$ & $\sqrt{ }$ & $\sqrt{ }$ & $\sqrt{ }$ & $\sqrt{ }$ & $\sqrt{ }$ & $\sqrt{ }$ \\
\hline $\begin{array}{l}\text { Forming the } \\
\text { class rules }\end{array}$ & $\sqrt{ }$ & $\sqrt{ }$ & & $\sqrt{ }$ & $\sqrt{ }$ & & $\sqrt{ }$ & & $\sqrt{ }$ & $\sqrt{ }$ & $\sqrt{ }$ & $\sqrt{ }$ \\
\hline $\begin{array}{c}\text { Not giving } \\
\text { unnecessary } \\
\text { details in the } \\
\text { lesson }\end{array}$ & & $\sqrt{ }$ & & $\sqrt{ }$ & $\sqrt{ }$ & & $\sqrt{ }$ & $\sqrt{ }$ & $\sqrt{ }$ & $\sqrt{ }$ & $\sqrt{ }$ & \\
\hline $\begin{array}{l}\text { Providing the } \\
\text { motivation }\end{array}$ & $\sqrt{ }$ & $\sqrt{ }$ & & $\sqrt{ }$ & $\sqrt{ }$ & & & $\sqrt{ }$ & & $\sqrt{ }$ & $\sqrt{ }$ & $\sqrt{ }$ \\
\hline $\begin{array}{l}\text { Attracting the } \\
\text { interest to the } \\
\text { subject }\end{array}$ & & $\sqrt{ }$ & & $\sqrt{ }$ & & $\sqrt{ }$ & $\sqrt{ }$ & $\sqrt{ }$ & & $\sqrt{ }$ & $\sqrt{ }$ & $\sqrt{ }$ \\
\hline $\begin{array}{l}\text { Controlling the } \\
\text { homeworks } \\
\text { regularly }\end{array}$ & $\sqrt{ }$ & $\sqrt{ }$ & $\sqrt{ }$ & & $\sqrt{ }$ & $\sqrt{ }$ & & & & & $\sqrt{ }$ & \\
\hline
\end{tabular}

As can be seen from Table 7, 6 codes emerged from the answers teachers gave to the fifth question of the interview. The code of "coming to the class with preparation" (12) is the foreground of these codes. This code was followed by "forming the class rules" (9), "not giving unnecessary details in the lesson" (8), "providing the motivation" (8), "attracting the interest to the subject" (8) "controlling the homeworks regularly" (6).

For the sixth question of the interview which was "How do events such as excursions, ceremonies, conferences on school influence your time management?" was answered by 12 teachers and the responses are given in Table 8. 
Table 8. The codes related to influence of events such as excursions, ceremonies, conferences on time management

\begin{tabular}{|c|c|c|c|c|c|c|c|c|c|c|c|c|}
\hline \multirow{2}{*}{ Codes } & \multicolumn{12}{|c|}{ Teachers (T) } \\
\hline & 19 & 20 & 21 & 22 & 23 & 24 & 25 & 26 & 27 & 28 & 29 & 30 \\
\hline $\begin{array}{l}\text { Affecting } \\
\text { negatively }\end{array}$ & $\sqrt{ }$ & & $\sqrt{ }$ & & $\sqrt{ }$ & $\sqrt{ }$ & $\sqrt{ }$ & & $\sqrt{ }$ & $\sqrt{ }$ & & \\
\hline $\begin{array}{l}\text { The need for } \\
\text { rapid } \\
\text { processing of } \\
\text { the course }\end{array}$ & $\sqrt{ }$ & $\sqrt{ }$ & & $\sqrt{ }$ & $\sqrt{ }$ & $\sqrt{ }$ & $\sqrt{ }$ & $\sqrt{ }$ & $\sqrt{ }$ & $\sqrt{ }$ & $\sqrt{ }$ & \\
\hline $\begin{array}{l}\text { Difficulty with } \\
\text { adaptation } \\
\text { afterwards }\end{array}$ & $\sqrt{ }$ & $\sqrt{ }$ & $\sqrt{ }$ & $\sqrt{ }$ & & & $\sqrt{ }$ & & & & $\sqrt{ }$ & $\sqrt{ }$ \\
\hline $\begin{array}{l}\text { Obligation to } \\
\text { do additional } \\
\text { courses }\end{array}$ & $\sqrt{ }$ & & $\sqrt{ }$ & & & $\sqrt{ }$ & & & $\sqrt{ }$ & & & $\sqrt{ }$ \\
\hline $\begin{array}{l}\text { Increasing the } \\
\text { motivation if } \\
\text { the activity is } \\
\text { related to the } \\
\text { lesson }\end{array}$ & $\sqrt{ }$ & & & $\sqrt{ }$ & & & $\sqrt{ }$ & & $\sqrt{ }$ & & & $\sqrt{ }$ \\
\hline
\end{tabular}

As can be seen from Table 8, 5 codes emerged from the answers teachers gave to the sixth question of the interview. The code of "affecting negatively" (7) is the foreground of these themes. This theme was followed by "the need for rapid processing of the course" (10), "difficulty with adaptation afterwards" (7), "obligation to do additional courses" (5) and "increasing the motivation if the activity is related to the lesson" (5).

\section{The Findings of "Communication" Dimension}

For the seventh question of the interview which was "What are you doing to overcome the difficulties of communication with the students in the class?" was answered by 10 teachers and the responses are given in Table 9.

Table 9. The codes related to overcome the difficulties of communication

\begin{tabular}{|c|c|c|c|c|c|c|c|c|c|c|}
\hline \multirow{2}{*}{ Codes } & \multicolumn{10}{|c|}{ Teachers $(\mathbf{T})$} \\
\hline & 31 & 32 & 33 & 34 & 35 & 36 & 37 & 38 & 39 & 40 \\
\hline Eye contact & $\sqrt{ }$ & $\sqrt{ }$ & $\sqrt{ }$ & $\sqrt{ }$ & $\sqrt{ }$ & $\sqrt{ }$ & $\sqrt{ }$ & $\sqrt{ }$ & $\sqrt{ }$ & $\sqrt{ }$ \\
\hline $\begin{array}{l}\text { Learning the names and } \\
\text { addressing them with their } \\
\text { names }\end{array}$ & $\sqrt{ }$ & $\sqrt{ }$ & $\sqrt{ }$ & $\sqrt{ }$ & $\sqrt{ }$ & $\sqrt{ }$ & & $\sqrt{ }$ & $\sqrt{ }$ & $\sqrt{ }$ \\
\hline $\begin{array}{l}\text { Finding personal information } \\
\text { and finding common } \\
\text { denominator }\end{array}$ & $\sqrt{ }$ & $\sqrt{ }$ & $\sqrt{ }$ & $\sqrt{ }$ & & $\sqrt{ }$ & & $\sqrt{ }$ & $\sqrt{ }$ & $\sqrt{ }$ \\
\hline $\begin{array}{l}\text { Behavior according to self- } \\
\text { sufficiency properties }\end{array}$ & $\sqrt{ }$ & $\sqrt{ }$ & $\sqrt{ }$ & & $\sqrt{ }$ & & & $\sqrt{ }$ & & $\sqrt{ }$ \\
\hline Notify the target & $\sqrt{ }$ & & $\sqrt{ }$ & & $\sqrt{ }$ & & $\sqrt{ }$ & & & \\
\hline $\begin{array}{l}\text { Communicating with the } \\
\text { family }\end{array}$ & & $\sqrt{ }$ & & $\sqrt{ }$ & & & $\sqrt{ }$ & & $\sqrt{ }$ & \\
\hline Sending to guidance service & & & $\sqrt{ }$ & & $\sqrt{ }$ & & & $\sqrt{ }$ & $\sqrt{ }$ & \\
\hline
\end{tabular}

As can be seen from Table 9, seven codes emerged from the answers teachers gave to the seventh question of the interview. The code of "eye contact" (10) is the foreground of these codes. This theme was followed by "learning the names and addressing them with their names" (9), "finding personal information and finding common denominator" (8), "behavior according 
to self-sufficiency properties" (6), "notify the target" (4), "communicating with the family" (4) and "sending to guidance service" (4).

The Findings of " Management Of Special Students in The Class" Dimension

For the eighth question of the interview which was "What kind of precautions will you take for a student is known to be special in your class?" was answered by 10 teachers and the responses are given in Table 10.

Table 10. The codes related to special students

\begin{tabular}{ccccccccccc}
\hline Codes & \multicolumn{10}{c}{ Teachers (T) } \\
\cline { 2 - 10 } & $\mathbf{4 1}$ & $\mathbf{4 2}$ & $\mathbf{4 3}$ & $\mathbf{4 4}$ & $\mathbf{4 5}$ & $\mathbf{4 6}$ & $\mathbf{4 7}$ & $\mathbf{4 8}$ & $\mathbf{4 9}$ & $\mathbf{5 0}$ \\
\hline Placing the student to the & $\sqrt{ }$ & $\sqrt{ }$ & $\sqrt{ }$ & $\sqrt{ }$ & $\sqrt{ }$ & $\sqrt{ }$ & $\sqrt{ }$ & $\sqrt{ }$ & $\sqrt{ }$ & $\sqrt{ }$ \\
front & & & & & & & & & & \\
Working on students' interests & $\sqrt{ }$ & $\sqrt{ }$ & $\sqrt{ }$ & $\sqrt{ }$ & $\sqrt{ }$ & $\sqrt{ }$ & $\sqrt{ }$ & $\sqrt{ }$ & $\sqrt{ }$ & $\sqrt{ }$ \\
Having funny activities & $\sqrt{ }$ & & $\sqrt{ }$ & $\sqrt{ }$ & $\sqrt{ }$ & & $\sqrt{ }$ & $\sqrt{ }$ & $\sqrt{ }$ & $\sqrt{ }$ \\
Trying to attract their interests & $\sqrt{ }$ & $\sqrt{ }$ & $\sqrt{ }$ & $\sqrt{ }$ & $\sqrt{ }$ & $\sqrt{ }$ & & & $\sqrt{ }$ & \\
Directing to special education & $\sqrt{ }$ & $\sqrt{ }$ & $\sqrt{ }$ & $\sqrt{ }$ & & & & $\sqrt{ }$ & $\sqrt{ }$ & $\sqrt{ }$ \\
if needed & & & & & & & & & & \\
$\quad \begin{array}{c}\text { Acting gently } \\
\text { Giving responsibility which }\end{array}$ & $\sqrt{ }$ & $\sqrt{ }$ & $\sqrt{ }$ & $\sqrt{ }$ & & & $\sqrt{ }$ & & $\sqrt{ }$ & $\sqrt{ }$ \\
they can be able to do & & & & & & & & & & \\
\hline
\end{tabular}

As can be seen from Table 10, 11 codes emerged from the answers teachers gave to the eighth question of the interview. The code of "placing the student to the front" (10) and "working on students' interests" are the foreground of these codes. This code was followed by "having funny activities" (8), "trying to attract their interests" (7), "directing to special education if needed" (7), "acting gently" (7), "giving responsibility which they can be able to do" (6), "communicating with the family" (6), "creating the appropriate environment" (6), "giving a word" (5) and "creating group activities" (4).

For the ninth question of the interview which was "What are the activities that you do for the students who are gifted, in order not to get bored, and are to be included in the class?" was answered by 10 teachers and the responses are given in Table 11.

Table 11. The codes related to gifted students

\begin{tabular}{|c|c|c|c|c|c|c|c|c|c|c|}
\hline \multirow{2}{*}{ Codes } & \multicolumn{10}{|c|}{ Teachers (T) } \\
\hline & 41 & 42 & 43 & 44 & 45 & 46 & 47 & 48 & 49 & 50 \\
\hline $\begin{array}{l}\text { Directing students to Science } \\
\text { and Art Centers }\end{array}$ & $\sqrt{ }$ & $\sqrt{ }$ & $\sqrt{ }$ & $\sqrt{ }$ & $\sqrt{ }$ & $\sqrt{ }$ & $\sqrt{ }$ & $\sqrt{ }$ & $\sqrt{ }$ & $\sqrt{ }$ \\
\hline $\begin{array}{l}\text { Specifying the level of the } \\
\text { students }\end{array}$ & $\sqrt{ }$ & $\sqrt{ }$ & $\sqrt{ }$ & & $\sqrt{ }$ & $\sqrt{ }$ & $\sqrt{ }$ & & $\sqrt{ }$ & $\sqrt{ }$ \\
\hline $\begin{array}{l}\text { Making appropriate teaching } \\
\text { and activities for the level }\end{array}$ & $\sqrt{ }$ & $\sqrt{ }$ & $\sqrt{ }$ & & $\sqrt{ }$ & $\sqrt{ }$ & $\sqrt{ }$ & & $\sqrt{ }$ & $\sqrt{ }$ \\
\hline $\begin{array}{c}\text { Creating the appropriate } \\
\text { environment }\end{array}$ & $\sqrt{ }$ & $\sqrt{ }$ & $\sqrt{ }$ & $\sqrt{ }$ & $\sqrt{ }$ & & $\sqrt{ }$ & & $\sqrt{ }$ & $\sqrt{ }$ \\
\hline $\begin{array}{c}\text { Making them accept each } \\
\text { other }\end{array}$ & $\sqrt{ }$ & & & $\sqrt{ }$ & & $\sqrt{ }$ & & & & $\sqrt{ }$ \\
\hline
\end{tabular}

As can be seen from Table 11, five codes emerged from the answers teachers gave to the ninth question of the interview. The code of "directing students to Science and Art Centers" (10) is the foreground of these codes. This code was followed by "specifying the level of the students" (8), "making appropriate teaching and activities for the level" (8), "creating the appropriate environment" (8) and "making them accept each other" (4). 


\section{DISCUSSION and CONCLUSION}

Considering that motivation positively affects success (Kaya, 2001), its importance in classroom management becomes apparent. A student who is not properly motivated may show some undesirable behavior and her/his success falls (Vatansever Bayraktar, 2015). A non-motivated student can not establish any relationship with his/her behavior and environment. For this reason, a non-motivated student can not be expected to fulfill his/her requirements (Boiche \& Sarrazin, 2007). Problems are encountered in classroom management due to lack or lack of interest and motivation towards the students in the classroom. In order to avoid problems caused by lack of motivation in classroom management, it is necessary for teachers to take into account the lesson related to real life, planning lessons considering the interests and needs of the students, informing the target, making group work, using visual materials and rewarding (Dönmez Usta \& Turan Güntepe, 2017). Besides, some of the strategies that can be used to motivate students in the classroom environment are to make the lesson interesting, to wake up students, to use rewards, to establish eye contact (Atherley, 2004; actin. Erdem, 2012). According to the findings of motivation, teachers stated that establishing eye contact, providing physical equipment, controlling assignments, informing the target and rewarding are necessary. These findings are compatible with the literature. In this case, it is possible to arrive at the conclusion that the teachers have to do what they need to do to ensure classroom management about the problems caused by lack of motivation and use them by shaping them according to the characteristics of their own students. Studies in the field of education show that academic motivation is the main determinant of academic performance and achievement (Green, Nelson, Martin and Marsh, 2006; Linnenbrink and Pintrich, 2002). A student with a high academic motivation will actively participate in the course, make effort, focus on the goal, and perform important learning tasks (Hidi \& Harackiewicz, 2000; Linnenbrink \& Pintrich, 2002). It is in line with the literature that teachers who participated in the study stated that selfconfidence was increased, the permanence of the learning was improved, the participation in the lectures was increased and focusing on the target was facilitated by the students having high motivation. In this case, it can be concluded that the teachers involved in the study are aware of the relationship between high motivation and learning. However, it is noteworthy that the teachers did not say that, students, who had high motivation, were sometimes worried about their feelings and that influenced their learning and success (Y1ldirım, 2011).

There are many reasons that disrupt the motivation of students in learning environments. These reasons may be of spiritual, sociological or organic origin. These include environmental and noise pollution, health problems, bad friends, economic and family reasons (Katipoğlu, 2012). Student motivation is influenced by teacher roles, classroom climate, organization of the class and interaction order in the classroom (Lumsden, 1999). In that case, high motivation is inevitable when students are respected, encouraged and homework is meaningful. In this context, it is in line with the literature that the teachers participating in the study stated that teachers did not relate the given information to daily life, the teachers were reluctant and established negative sentences, the students were found to be in undesirable behaviors, the answers to the questions were wrong and their friends were ridiculed and decreasing the self-confidence. In this case, it can be said that the teachers who participated in the study know the behaviors that disturb the motivation. In addition, teachers had stated that students had the motivation to have technological tools such as tablets, smartphones, and laptops. This may be due to the active use of social networks and games (Turan Güntepe \& Dönmez Usta 2017a,b). In this content; it is recommended to raise awareness in this subject since it is sufficient that the games and social networks are limited.

All of the teachers who responded to the question about managing time effectively in the study stated that they should come to the school in a planned manner. According to literature, effective use of time in class is the most important occupational and proficiency indicator of the teacher (Şişman and Turan, 2004). With effective time management, students are directed to regular, balanced work. Teachers set an example for students in terms of time management. In order to be able to use time efficiently in the lesson, the teacher must finish the work which has started well with good planning time (Livatyal1, 2004). In addition, the teachers, who participate of this study, think that teachers should consider the creation of the class rules, the lack of unnecessary detail, motivation, attention, and regular homework controlThis situation is in parallel with the literature. Pre-designation of rules to be applied to the class 
will enable both the reduction of unwanted behavior and the appropriate use of time (Erdem, 2001). Teachers think that motivation should be provided to use time effectively because of that the students are engaged in learning activities and that they are actively engaged in learning activities (Ekici, 2002). This can contribute positively to learning. It is noteworthy that teachers did not talk about time management approaches to managing time effectively. This is thought to be due to the fact that the teachers are based on the behaviors that include time approaches but do not know which behavior is intended for which approach. In addition, teachers responding to this question should have experience ranging from eight months to 25 years (Table 1), supporting the fact that the new graduate teachers in the sample do not mention their time management approach.

According to the findings obtained related to time trap, activities such as school trips, conferences, and ceremonies are considered to negatively affect time management, suggesting that teachers are taking precautions in time traps in order to conduct additional courses after these activities or to process faster lessons. Also, these teachers are trying to cope with disruptions by showing behavior such as taking a break, warning, making jokes, classroom setting, making agreements, notifying the guidance service, changing the setting and notifying the family when they encounter classroom and classroom disturbances that affect the use of time. This state can be explained by the way the teachers shape their behavior to the students according to their characteristics and the importance of the disruption. Furthermore, teachers are thought to have contributed positively to time management with these behaviors. This opinion shows with agreed precautions should be taken by determining the time traps in learning environments in the literature (Güçlü, 2001; Gürbüz \&Aydın, 2012).

According to the findings obtained related to communication, teachers' awareness of the importance of communicating with the family over the difficulties of communicating with the students. It is thought the teachers' awareness is good for learning environments. All of the teachers stated that eye contact related to communication is important (Table 9). Also, almost all of the teachers said important learning the names and addressing them with their names. According to Jones and Jones (1998), teachers who are the designers of the learning environments should pay attention to the current situation, to take responsibility for expressions using personal pronouns, direct conversation with the student, gentle conversation, eye communication and awareness of nonverbal communication in developing the relationship with the students. In this respect, it is in line with the literature that teachers establish eye contact with communication difficulties encountered in the class, find common denominators by learning their names and personal information, behave according to their self-efficacy characteristics, inform the target, communicate with the family and send them to the guidance service. On the other hand, the fact that parents do not communicate with their teachers about the success of their children can push them to fail in academic life (Kaufman, Bradby \& Owings, 1992). Students gain social norms and values first in the family (Celep, 2008). Some teachers state that important of communicating with the family and sending to guidance services in this study. This situation is thought to be important for awareness. Besides, it is stated that teachers use guidance service more frequently in such subjects as school failure and vocational guidance in the literature (Meşeci, Özcan \& Bozdemir, 2007).

As a result of this study, teachers stated placing the student to the front, working on students' interests, having fun activities and trying to attract their interests for special students. Considering students have different individual characteristics in learning environments, it may true of the teacher implementation for special students. Some students need special education, either physically and mentally, or from inherited characteristics such as language, which affect class performance (Emmer, Evertson, Clements \& Worsham, 1997). It is defined as the learning difficulty that students have in acquiring, and using the skills of reading, writing, arithmetic, listening, speaking, and reasoning (Yavuzer, 2003). Teachers with learning difficulties in their classrooms need to be careful to teach according to the level of the students, to clearly place in the directives, and to place them in the classroom (Özsoy, Özyürek \& Eripek, 1998). In this respect, when a student known to be special to their class participates, the teachers should primarily place them front seats, should make them work for their interests, have fun activities and try to attract their attention. In addition, it can be said that the teachers behave correctly when they think that the students with learning disabilities need more help from other students to learn, to summarize their attention and get a clue (Celep, 2008). Students with low achievement need to be seated where they can get help to improve communication with teachers and friends (Celep, 2008). In this respect, it is 
important for teachers to seat such students to the front in order to increase the communication of the learners as well as to increase their academic success.

According to teachers, it is important to make teaching and activities appropriate to the students' levels, to create a suitable environment and to make students accept each other. It is also important to provide a suitable environment for the level of students, where they can be provided help or are directed to the science arts center to be provided for further assistance. Learning can be easier in the learning environment of teachers who consider these situations.

When looking at the data obtained from the study, the teachers are in different branches and their experience shows little change in relation to the classroom management, time, motivation, and management of special students in class. For example, science and similar branch teachers prefer to have different activities such as experimentation to motivate. In this case, it is possible that teachers may be able to take precautions in order to guide students to take lessons according to the characteristics of their branches and avoiding unwanted student behavior in class. In fact, it can be said that teachers generally know what to do in learning environments related to classroom management. What is important here is that teachers should do what they need to do at the right time and in appropriate behavior. Experience is guiding teachers in this regard. It is thought that this study contributed to the literature at this point. In this context, it is proposed to study the ways of observing how teachers behave in learning environments in providing classroom management.

\section{Acknowledgement/Bilgilendirme:}

1-The contribution rates of the researchers are equal.

2-This study was supported by the Giresun University Scientific Research Project Unit as a project (The project code: EĞTBAP-A-140316-111.)

3- Research data was collected and used before 2020 .

4-There is no conflict of interest among the authors of the article.

5 In this article, research and publication ethics were followed.

\section{REFERENCES}

Ağaoğlu, E. (2008). Sinıf yönetimi ile ilgili genel olgular, sinıf yönetimi. Ankara: PEGEM.

Akın, U. \& Koçak, R. (2007). Öğretmenlerin sınıf yönetimi becerileri ile iş doyumları arasındaki ilişki. Kuram ve Uygulamada Eğitim Yönetimi, 51, 353-370.

Arsal, Z. (2014). Mikro öğretimin öğretmen adaylarının sınıf yönetimi inançlarına etkisi. Mersin Üniversitesi Ë̆itim Fakültesi Dergisi, 10(3), 137-150.

Atıc1, M. (2002). Öğrenci istenmeyen davranışlarıyla baş etmede türk ve ingiliz öğretmenlerin kullandıkları yöntemlerin karşılaştırılması. Kuram ve Uygulamada Ĕgitim Yönetimi Dergisi, 29, 926.

Aydın, A. (2000). Sinıfyönetimi, Ankara: Anı Yayıncılık.

Aydın, M. (1998). Eğitim yönetimi. Ankara: Hatiboğlu Yayınevi.

Başar, H. (2004). Sinıf yönetimi, Ankara: Pegem Yayınları.

Bauer Martin. W. (2003). Classical content analysis: A review. In Qualitative researching with text, image and sound. M. W. Bauer \& G. Gaskell (Eds). (pp.131). London: Sage Publication.

Boiché, J. \& Sarrazin, P. (2007). Motivation autodéterminée, perceptions de conflit et d'instrumentalité et assiduité envers la pratique d'une activité physique: une étude prospective sur six mois. Psychologie Française, 52, 417- 430.

Brissie, J. S., Hoover-Dempsey, K. V. \& Bassler, O. C. (1988). Individual, situational contributors to teacher burnout. Journal of Educational Research, 82(2), 106-112.

Brophy, F. (1988). Educating Teachers about managing classroom and students. Teaching and Teacher Education, 4(1), 1-18. 
Brophy, J. E. (1983). Classroom organization and management. The Elementary School Journal, 83(4), 265-285.

Burden, P. R. (1995). Classroom management and discipline: Methods to facilitate cooperation and instruction. Londra: Longman.

Celep, C. (2008). Sinlf yönetiminde kuram ve uygulama. (3. baskı). Ankara: PegamA Yayınları.

Çelik, İ. (2006). Kaynaştırma sınıfi ve özel sinıf öğretmenlerinin sinıflarındaki zihin engelli öğrencilere yönelik ödül ve ceza uygulamalarının belirlenmesi. Yayınlanmamış yüksek lisans tezi, Abant İzzet Baysal Üniversitesi Sosyal Bilimler Enstitüsü, Bolu.

Çepni, S. (2007). Araştırma ve proje çalışmalarına giriş. (Genişletilmiş 3. Baskı). Trabzon: Celepler Matbaacilik.

Çitil, M. ve Ataman, A. (2018). İlköğretim çağındaki üstün yetenekli öğrencilerin davranışsal özelliklerinin eğitim ortamlarına yansıması ve ortaya çıkabilecek sorunlar. Gazi Üniversitesi Gazi Eğitim Fakültesi Dergisi, 38(1), 185-231.

Cohen, L. \& Manion, L. (1994). Research methods in education $\left(4^{\text {th }}\right.$ Ed.). New York: Routledge.

Creswell, J. W., Plano Clark, V. L., Gutmann, M. L. \& Hanson, W. E. (2003). Advanced mixed methods research designs. Handbook of mixed methods in social and behavioral research, 209-240.

Demirtaş, H. (2006). Yönetim kuram ve yaklaşımları eğitiminin ilköğretim okulu öğretmenlerinin sınıf yönetimi paradigmalarına etkileri. Eğitimde Politika Analizleri ve Stratejik Araşstırmalar Dergisi (INASED), 1(1), 49-70.

Demirtaş, Z. ve Kahveci, G. (2010). Öğrenci algilarina göre 4. sinıf ve 5. sınıf öğretmenlerinin sinıf yönetimi yeterlikleri. Dicle Üniversitesi Ziya Gökalp Eğitim Fakültesi Dergisi, 15, 18-29.

Dönmez Usta, N. ve Turan Güntepe, E. (2017). Öğretmen adaylarının geliştirdikleri materyallerin değerlendirilmesi: etkili bir sınıf yönetimi örneği. Avrasya Sosyal ve Ekonomi Araştırmaları Dergisi, 4(7), 102-115.

Dönmez Usta, N. ve Turan Güntepe, E. (2019). Öğrenme ortamında QR kod destekli materyallerin kullanımı. Bolu Abant İzzet Baysal Üniversitesi Eğitim Fakültesi Dergisi, 19(3), 923-935.

Drew, C. J., Hardman, M. L. \& Hart, A. W. (1996). Designing and conducting research: Inquiry in education and social science ( $2^{\text {nd }}$ Ed.). Boston: Allyn and Bacon.

Edwards, C. H. (1993). Classroom discipline and management. NY: Macmillan

Ekici, G. (2002). Öğretimin yönetimi. Sinıf yönetimi. Ankara: Pegem A Yayınc1lık.

Ekici, G., Aluçdibi, F., ve Öztürk, N. (2012). Biyoloji öğretmenlerinin sınıf yönetimi profillerinin cinsiyet ve kıdem değişkenleri açısından incelenmesi. Dicle Üniversitesi Sosyal Bilimler Enstitüsü Dergisi, 4(8), 13-30.

Emmer, E., Evertson, C., Clements, B. \& Worsham, M. (1997). Managing problem behaviors. Classroom management for secondary teachers.

Erdem, A.R.,(2012). Sınıfta güdüleme. In Etkili sınıf yönetimi. Ed. Hüseyin Kıran. Ankara: Anı Yayınc1lik.

Erdem, M. (2001). Sinıf yönetimi. İstanbul: Alkım Yayınevi.

Erden, M. (1998). Öğretmenlik mesleğine giriş. İstanbul: Alkım Yayınevi.

Erdoğan, M., Kurşun, E., Şişman, G. T., Saltan, F., Gök, A. ve Yıldız, İ. (2010). Sınıf yönetimi ve sınıf içi disiplin problemleri, nedenleri ve çözüm önerileri üzerine nitel bir araştırma: Bilişim teknolojileri dersi örneği. Kuramdan Uygulamaya Eğitim Bilimleri-Educational Sciences: Theory and Practice, 10(2), 853-891.

Erol, Z. (2006). Sinıf öğretmenlerinin sınıf yönetimi uygulamalarına ilişkin görüşleri. Yayınlanmamış yüksek lisans tezi, Afyon Kocatepe Üniversitesi Sosyal Bilimler Enstitüsü, Afyon.

Glasser, W. (1990). The quality school: Managing students without coercion. New York: Harper and Row Publishers, Inc. 
Green, J., Nelson, G., Martin, A. J. \& Marsh, H. (2006). The causal ordering of selfconcept and academic motivation and its effect on academic achievement. International Education Journal, 7 , $534-546$.

Güçlü, N. (2001). Zaman yönetimi. Kuram ve Uygulamada Eğitim Yönetimi, 25(25), 87-106.

Güleryüz, Ş. O., (2009). Kaynaştırma eğitimine devam eden engelli öğrencilerin akranları ile ilişkilerinde karşılaştıkları sorunların değerlendirilmesi. Yayınlanmış yüksek lisans tezi, Selçuk Üniversitesi Eğitim Bilimleri Enstitüsü, Konya.

Gündüz, M. (2014). İlkokul öğrencilerinin etkili öğretmen hakkındaki düşünceleri. Yüzüncü Yıl Üniversitesi Ĕgitim Fakültesi Dergisi, 11(1), 114-128.

Gürbüz, M., ve Aydın, A. H. (2012). Zaman kavramı ve yönetimi. Kahramanmaraş Sütçü İmam Üniversitesi Sosyal Bilimler Dergisi, 9(2), 1-20.

Güven, E. D., ve Cevher, N. (2005). Okul öncesi öğretmenlerinin sınıf yönetimi. Pamukkale Üniversitesi Ĕgitim Fakültesi Dergisi, 18(18), 71-92.

Güven, S. ve Akdağ, M. (2002). İlköğretim ikinci kademe öğretmenlerinin sınıf yönetimi etkinliklerine ilişkin öğrenci algıları. Kuram ve Uygulamada Ĕ̈itim Yönetimi Dergisi, 29, 69-80.

Hidi, S. \& Harackiewicz, J. M. (2000). Motivating the academically unmotivated: A critical issue for the 21st century. Review of Educational Research, 70, 151-179.

Jones, V. F. \& Jones, L. S. (1998). Comprehensive classroom management: creating communities of support and solving problems. (5th ed.). Boston: Allyn and Bacon.

Katipoğlu, B. (2012). Öğrencilerde dikkat ve motivasyon zafiyetine neden olan bazı faktörler. Balıkesir University Journal of Social Sciences Institute, 15(27), 225-235.

Kaufman, P., Bradby, D. and Owings, J. (1992). National education longitudinal study of 1988: Characteristics of at-risk students in NELS: 88@ Contractor Report, NCES 92-042\#. Washington, DC: US Department of Education, Office of Educational Research and Improvement. National Center for Education Statistics.

Kaya, Z., (2001). Eğitimin psikolojik temelleri. In Öğretmenlik mesleğine giriş. Ed. Özcan Demirel. Ankara: Pegem Yayıncilik

Kazu, H. (2007). Öğretmenlerin sınıfta istenmeyen davranışlarının önlenmesi ve değiştirilmesine yönelik stratejileri uygulama durumları. Milli Ë̆itim, 175, 57-66.

Lewis, R. (2001). Classroom discipline and student responsibility: the students' view. Teaching and Teacher Education, 17, 307-319.

Lincoln, Y. S. \& Guba, E. G. (1985). Naturalistic inquiry. California: Sage Publications, Inc.

Linnenbrink, E. A. \& Pintrich, P. R. (2002). Motivation as an enabler for academic success. The School Psychology Review, 31, 313-327.

Livatyalı, H. (2004). Zaman yönetimi ve okul. Sinıf yönetimi. Konya: Eğitim Kitabevi.

Lumsden, L. (1999). Student motivation: cultivating a love of learning. ERIC Clearinghouse on Educational Management, 5207 University of Oregon, Eugene, OR 97403-5207.

Meşeci, F., Özcan, N. ve Bozdemir, P. (2007). Öğretmen ve müdürlerin okul psikolojik danışma ve rehberlik servisine yönelik algıları. Hasan Âli Yücel Eğitim Fakültesi Dergisi, 4(1), 151-171.

Miles, M. B. \& Huberman, A. M. (1994). Qualitative data analysis. (2nd Ed.). California: Sage Publications, Inc.

Nakamura, R. M. (2000). Healthy classroom management:motivation. Communication and discipline. USA.

Nelson, M. F. (2002). A qualitative study of effective school discipline practices: Perceptions of administrators, tenured teachers and parents in twenty schools. Unpublished doctoral dissertation, East Tennessee State University, Tennessee.

Öksüz, Y., Çevik, C., Baba, M., \& Güven, E. (2011). Sınıf öğretmeni adaylarının sınıf yönetimine ilişkin algılarının çeşitli değişkenler açısından incelenmesi. Retriewed from 
https://openaccess.bayburt.edu.tr/xmlui/handle/20.500.12403/1590\#sthash.fsSdFygF.dpbs on 1 February 2019.

Özsoy, Y., Özyürek, M. ve Eripek, S. (1998). Özel eğitime giriş. Ankara: Karatepe Yayınları.

Sadioğlu, Ö., Batu, E. S. ve Bilgin, A. (2012). Sinıf öğretmenlerinin özel gereksinimli öğrencilerin kaynaştırılmasına ilişkin görüşleri. Uludağ Üniversitesi Eğitim Fakültesi Dergisi, 25(2), 399-432.

Schwab, R. L., Jackson, S. E. \& Schuler, R. S. (1986). Toward an understanding of the burnout phenomenon. Journal of Applied Psychology, 71(4), 630-640.

Şentürk. H. (2007). Uygulama liselerindeki rehber öğretmenlerin sınıf yönetimi yaklaşımları. Dicle Üniversitesi Ziya Gökalp Eğitim Fakültesi Dergisi, 8, 7-16.

Sezer, Ş. (2015). Üstün yeteneklilerin sınıf içindeki olumsuz davranışları ve yönetilmesine ilişkin öğretmen görüşleri. Uluslararası Türk Eğitim Bilimleri Dergisi, (4), 317-333.

Şimşek, Y. ve Altınkurt, Y. (2010). Genel lise öğretmenlerinin sınıf yönetimi çerçevesinde iletişim özelliklerinin belirlenmesi. Eğitimde Kuram ve Uygulama, 6(1), 36-49.

Şişman, M. ve Turan, S. (2004). Sinıf yönetimi. Ankara: Pegem Yayıncılık.

Turan Güntepe, E. \& Dönmez Usta, N. (2017a). Technology readings in education. In Game based learning (Oyun Tabanlı Öğrenme). (s. 917-932). ed. A. İsman, H. F. Odabaşı, and B. Akkoyunlu. TOJET Online Books. http://www.tojet.net/e-book/eto 2017.pdf

Turan Güntepe, E. ve Dönmez Usta, N. (2017b). Okul öncesi öğretmen adaylarının perspektifinden eğitsel bilgisayar oyunları. Yüzüncü Yıl Üniversitesi Eğitim Fakültesi Dergisi, 14(1), 1095-1116.

Türnüklü, A. ve Yıldız, V. (2002. Öğretmenlerin öğrencilerin istenmeyen davranışlarıyla başa çıkma stratejileri. Çă̆daş Ĕ̈itim, 284, 22-27.

Ültay, E. ve Ültay, N. (2015). Okul öncesi öğretmen adaylarının bazı fen kavramları hakkındaki kavramsal bilgilerinin kesitsel olarak incelenmesi. Uluslararası Sosyal Araştırmalar Dergisi, 8(41), 1046-1051.

Ültay, E., Ültay, N. ve Dönmez Usta, N. (2018). Sınıf öğretmeni adaylarının "basit elektrik devreleri” konusunda 5E modeli ve REACT stratejisine uygun hazırladıkları ders planlarının incelenmesi. Kastamonu Üniversitesi Kastamonu Eğitim Dergisi, 26(3), 855-86.

Vatansever Bayraktar, H. (2015). Sınıf yönetiminde öğrenci motivasyonu ve motivasyonu etkileyen etmenler. Turkish Studies, 10(3), 1069-1090.

Wellington, J. (2000). Educational Research. In Contemporary issues and practical approaches. London, UK: Continuum.

Wragg, E. C. (1993). Class management. London: Routledge.

Yavuzer, H. (2003). Okul çă̆ı çocuğu. İstanbul: Remzi yayınları.

Yıldırım, A. ve Şimşek, H. (2011). Sosyal bilimlerde nitel araştırma yöntemi. (8. Baskı). Ankara: Seçkin Yayıncilik.

Yıldırım, S. (2011). Öz-yeterlik, içe yönelik motivasyon, kaygı ve matematik başarısı: Türkiye, Japonya ve Finlandiya'dan bulgular. Necatibey Eğitim Fakültesi Elektronik Fen ve Matematik Eğitimi Dergisi, 5(1), 277-291.

Yin, R. K. (2003). Case study research: design and methods (ed.). USA: Thousand Oaks. 